\title{
EVALUASI KESESUAIAN LAHAN UNTUK TANAMAN DURIAN MENGGUNAKAN METODE MATCHING
}

\author{
Muhammad Frido Saputra Al Bana'mah ${ }^{\mathrm{a}}$, Sidharta Adyatma ${ }^{a}$, Deasy Arisanty ${ }^{\mathrm{a}}$ \\ ${ }^{a}$ Program Studi Pendidikan Geografi, FKIP, Universitas Lambung Mangkurat, Jalan Beigjen Haji Hasan Basri, Kota \\ Banjarmasin (70123), Indonesia
}

\section{ARTICLE INFO}

\section{Article history:}

Received: 15 April 2020

Accepted: 13 January 2021

Published: 19 January 2021

\section{Keywords:}

Land Characteristics; Land Suitability; Matching Methods; Productivity

\section{Corresponding author:}

Muhammad Frido Saputra Al Bana'mah Universitas Lambung Mangkurat,

Kota Banjarmasin, Indonesia

Email: fridosaputra2@gmail.com

\begin{abstract}
Land suitability evaluation is a process of assessing the potential of land for a particular use, whether in agriculture, plantation, tourism, land conservation, or other types of use. This study aims to determine the land suitability class for durian plants in Aranio District and determine the inhibiting factors on the land using the matching method. The population in this study was 12 land units and each unit was taken 2 samples. Land units are obtained from overlay maps of landforms, slope maps, geological maps, soil association maps, and land use maps. The results showed that the land in Aranio District was included in the suitability class S2 (moderately suitable) with an area of 15069.68 hectares or $33.13 \%$, S3 (marginally suitable) with an area of 1485.78 hectares or $3.27 \%$, and N1 (not current suitable) with an area of 3980.03 hectares or $8.75 \%$. The limiting factor is slope, erosion hazard, $\mathrm{pH}$, soil depth, surface rock, alkaline saturation, flood hazard, phosphate, $\mathrm{K} 2 \mathrm{O}$, and $\mathrm{N}$-Total. The villages in the Aranio sub-district are used to develop durian plants because they have land suitability classes of S2 and the use of shrubs, fields, and mixed gardens are above $50 \%$, namely Tiwingan Baru and Tiwingan Lama villages.
\end{abstract}

Copyright $(\mathrm{C} 2021$ The Authors This open access article is distributed under Creative Commons Attribution (CC-BY) 4.0 International license

\section{Pendahuluan}

Perencanaan penggunaan lahan memerlukan evaluasi kesesuaian lahan untuk mengurangi risiko kegagalan dalam penggunaan lahan dan meningkatkan nilai ekonomi lahan tersebut. Kesesuaian lahan digunakan untuk memperoleh wilayah yang sesuai dengan kondisi lansekap dan jenis tanah untuk tanaman tertentu (Nugroho, 2017). Petani yang membudidayakan tanaman holtikultura banyak yang tidak mengetahui tingkat kesesuaiannya karena kurangnya pengetahuan mengenai kesesuaian lahan. Petani hanya menanam tanaman saja tetapi tidak tahu apakah lahan cocok atau tidak untuk ditanami dengan tanaman tersebut. Tingkat kesesuaian lahan dapat diketahui melalui evaluasi kesesuaian lahan (Safitri, 2015; Arisanty \& Syarifuddin, 2018). Evaluasi kesesuaian lahan menilai potensi lahan berdasarkan pada sifat fisik lingkungan seperti iklim, tanah, topografi dan hidrologi untuk berbagai keperluan di bidang pertanian, perkebunan, pariwisata, konservasi lahan atau jenis penggunaan lainnya (Sitorus, 1985; Anggraini, 2011; Djaenuddin et al., 2011). Kesesuaian lahan perlu memperhatikan karakteristik dari tanaman karena tanaman mempunyai karakteristik yang berbeda untuk dapat tumbuh dan berproduksi secara optimal (Djaenuddin et al., 2011).

Tanaman durian merupakan salah satu tanaman hortikultura asli Indonesia dan termasuk 10 prioritas komoditi hortikultura nasional yang ditetapkan oleh pemerintah (Tim Agro Mandiri, 2016). Tanaman durian banyak ditemui di hutan tropis seperti Kalimantan, Sumatera, dan Irian. Pohon durian dihabitatnya tumbuh liar dari hutan tropis Asia Tenggara menyebar ke barat Thailand, Birma, India dan Pakistan (Pertama \& Syukur, 2014; Tim Agro Mandiri, 2016). Durian banyak ditemukan di daerah yang memiliki ketinggian 80-100 mdpl, umumnya dapat tumbuh baik di dataran rendah sampai 
menengah daerah perbukitan, suhu berkisar antara $25-28^{\circ} \mathrm{C} /$ tahun dan intensitas curah hujan 2.000$3.000 \mathrm{~mm}$ /tahun (Balai Besar Penelitian dan Pengembangan Sumber Daya Lahan Pertanian, 2011).

Provinsi Kalimantan Selatan merupakan salah satu pemasok durian di negara Indonesia dan hampir seluruh kabupaten dan kota memproduksi durian, kecuali Kota Banjarmasin. Rata-rata luas panen dan produksi tanaman durian di Provinsi Kalimantan Selatan tahun 2014-2018 tertinggi terdapat di Kabupaten Banjar. Tanaman durian termasuk salah satu komoditas unggulan di Kabupaten Banjar, selain tanaman padi, jeruk dan pisang. Durian unggul yang terdapat di Kabupaten Banjar adalah si dodol, si sirih, si panjang tangkai, si katuyung, si gantang, si penyengat, si bujang, si manalagi, si airmata, si tembaga dan si penganten (Badan Pusat Statistik Kabupaten Banjar, 2018).

Jumlah pohon durian terbanyak di Kabupaten Banjar terdapat di Kecamatan Karang Intan, Simpang Empat dan Aranio. Durian di Kecamatan Aranio tumbuh secara liar dan bukan termasuk daerah pengembangan durian, namun jumlah pohonnya termasuk yang terbanyak di Kabupaten Banjar dengan jumlah 9.692 buah. Akan tetapi hasil produksi rata-ratanya dari tahun 2014-2018 hanya menempati urutan ke 5 di Kabupaten Banjar. Sementara Kecamatan Pengaron dan Sumbung Makmur yang memiliki jumlah pohonnya lebih sedikit, tetapi memiliki hasil produksi yang lebih tinggi. Kecamatan Aranio memiliki jumlah pohon durian yang banyak dan berpotensi untuk dikembangkan jika dilakukan perbaikan kualitas lahan untuk meningkatkan hasil produksinya (Badan Pusat Statistik Kabupaten Banjar, 2018). Hasil produksi yang rendah disebabkan karena adanya faktor pembatas yang menghambat produksi durian. Faktor pembatas yang mempengaruhi durian yaitu temperatur, curah hujan, tekstur, kedalaman efektif, kapasitas tukar kation, $\mathrm{pH}$, bahan organik, N-total, phosfat, kadar kalium, bahaya erosi, kemiringan lereng, bahaya banjir, batuan permukaan, singkapan batuan (Balai Besar Penelitian dan Pengembangan Sumber Daya Lahan Pertanian, 2011).

Prasyat tanaman perlu diperhatikan agar tanaman dapat tumbuh dan berproduksi maksimal. Tinggi rendahnya produksi ditentukan oleh faktor genetik dan lingkungan tumbuhnya. Apabila cocok dengan lingkungan tumbuhnya, maka tanaman dapat berproduksi dengan baik (Takliviyah, 2016). Persyaratan penggunaan lahan yang diperlukan oleh masing-masing komoditas, termasuk tanaman durian, mempunyai batas kisaran minimum, optimum dan maksimum untuk masing-masing karakteristik lahan. Karakteristik lahan yang menjadi pembatas dapat diperbaiki. Apabila dilakukan perbaikan pada karakteristik lahannya maka kelas kesesuaian dapat berubah menjadi lebih baik satu tingkat atau dua tingkat. Perbaikan pada pembatas lahan tersebut akan mempengaruhi produksi tanaman (Hardjowigeno \& Widiatmaka, 2011).

Penentuan alternatif kawasan pengembangan durian dapat dilakukan dengan analisis spasial, yaitu dengan melakukan pemetaan kesesuaian lahan untuk tanaman durian. Hal tersebut untuk dimaksudkan agar tanaman durian dapat tumbuh optimal. Oleh karena itu pemilihan lokasi yang tepat akan menentukan keberhasilan budidaya dan tentunya mengurangi energi yang dibutuhkan termasuk biaya dalam melakukan budidaya (Achadiah, 2016). Penelitian ini bertujuan untuk mengetahui tingkat kesesuaian lahan dan faktor-faktor pembatas untuk tanaman durian di Kecamatan Aranio Kabupaten Banjar, yang dapat dijadikan rekomendasi dalam upaya memperbaiki faktor pembatas yang ada di lapangan, agar hasil produksi durian bisa maksimal.

\section{Metode}

\subsection{Lokasi Penelitian}

Penelitian berlokasi di Kecamatan Aranio, Kabupaten Banjar yang memiliki letak astronomis $3^{\circ} 9^{\prime} 34^{\prime \prime} L S-115^{\circ} 5^{\prime} 13^{\prime \prime}$ BT dan $3^{\circ} 17^{\prime} 58^{\prime \prime}$ LS $115^{\circ} 5^{\prime} 13^{\prime \prime}$ BT dan memiliki letak geografis bagian timur berbatasan dengan Kabupaten Tanah Bumbu, bagian selatan berbatasan dengan Kabupaten Tanah Laut, bagian utara berbatasan dengan Kecamatan Pengaron dan bagian selatan berbatasan dengan Kecamatan Karang Intan (Badan Pusat Statistik Kabupaten Banjar, 2018). Kecamatan Aranio memiliki luas wilayah $1166.35 \mathrm{~km}^{2}$, yang terbagi menjadi $12 \mathrm{desa}$, yaitu Apuai $\left(69.22 \mathrm{~km}^{2}\right)$, Aranio $\left(20.07 \mathrm{~km}^{2}\right)$, Artain $\left(69.92 \mathrm{~km}^{2}\right)$, Belangian $\left(121.95 \mathrm{~km}^{2}\right)$, Benua Riam $\left(59.46 \mathrm{~km}^{2}\right)$, Bunglai $(80.80$ $\mathrm{km}^{2}$ ), Kalaan $\left(93.54 \mathrm{~km}^{2}\right)$, Paau $\left(45,90 \mathrm{~km}^{2}\right)$, Rantau Balai $\left(136.59 \mathrm{~km}^{2}\right)$, Rantau Bujur $\left(313.52 \mathrm{~km}^{2}\right)$, Tiwingan Baru (125.87 km²), Tiwingan Lama $\left(29.41 \mathrm{~km}^{2}\right)($ Gambar 1).

\subsection{Alat dan Bahan}

Penelitian menggunakan GPS (Global Positioning Sistem), yallon, abney level, bor tanah, $\mathrm{pH}$ stick, roll meter, munsell, kamera, pisau/parang, plastik sampel, ring sampel, tabung reaksi, aquades, alat tulis, dan tali. Bahan yang digunakan dalam penelitian adalah sampel tanah, peta penggunaan lahan, peta 




Gambar 1. Peta administrasi lokasi penelitian

bentuk lahan, peta jenis tanah, peta kemiringan lereng, peta geologi, peta administrasi Kecamatan Aranio, dan bahan kimia untuk uji laboratorium.

Parameter yang digunakan dalam evaluasi kesesuaian lahan untuk tanaman durian mengacu pada Balai Besar Penelitian dan Pengembangan Sumber Daya Lahan Pertanian tahun 2011 yaitu temperatur rata-rata $\left({ }^{\circ} \mathrm{C}\right)$, curah hujan $(\mathrm{mm})$, tekstur, kedalam tanah, $\mathrm{KTK}$ tanah, kejenuhan basa, $\mathrm{pH}$, C-organik, Iereng (\%), bahaya erosi, genangan, batuan dipermukaan (\%), singkapan batuan (\%), kadar $\mathrm{N}$ total (\%), $\mathrm{K}_{2} \mathrm{O}(\mathrm{mg} / 100 \mathrm{~g}), \mathrm{P}_{2} \mathrm{O}_{5}(\mathrm{mg} / 100 \mathrm{~g})$. Teknik pengumpulan data disajikan pada Tabel 1.

Tabel 1. Jenis dan sumber data yang digunakan dalam penelitian

\begin{tabular}{|c|c|c|c|}
\hline No & Jenis data & Sumber data & Teknik pengumpulan data \\
\hline 1 & Kedalaman Tanah & Primer & $\begin{array}{l}\text { Pengukuran langsung dengan mengukur } \\
\text { kedalam akar masuk kedalam tanah } \\
\text { menggunakan rool meter. }\end{array}$ \\
\hline 2 & Kemiringan Lereng & Primer & $\begin{array}{l}\text { Pengukuran langsung dengan menggunakan } \\
\text { yallon dan abney level }\end{array}$ \\
\hline 3 & Bahaya Erosi & Primer & $\begin{array}{l}\text { Pengamatan langsung erosi yang terjadi di } \\
\text { lokasi penelitian }\end{array}$ \\
\hline 4 & Bahaya Banjir & Primer & $\begin{array}{l}\text { Wawancara dengan warga sekitar lokasi } \\
\text { penelitian }\end{array}$ \\
\hline 5 & $\begin{array}{l}\text { Batuan Permukaan dan } \\
\text { Singkapan Batuan }\end{array}$ & Primer & $\begin{array}{l}\text { Pengukuran langsung menggunakan ring } \\
\text { sampel ukuran } 1 \mathrm{~m}^{2}\end{array}$ \\
\hline 6 & $\mathrm{pH}$ & Primer & $\begin{array}{l}\text { Pengukuran langsung menggunakan tabung } \\
\text { reaksi, aquades dan } \mathrm{pH} \text { stick }\end{array}$ \\
\hline 7 & $\begin{array}{l}\text { C-Organik (\%), Kejenuhan } \\
\text { Basa (\%), KTK tanah, N } \\
\text { Total }(\%), \mathrm{P}^{2} \mathrm{O}^{5}(\mathrm{mg} / 100 \mathrm{~g}) \\
\mathrm{K}^{2} \mathrm{O}(\mathrm{mg} / 100 \mathrm{~g}), \text { Tekstur }\end{array}$ & Primer & $\begin{array}{l}\text { Pengambilan sampel tanah menggunakan } \\
\text { bor tanah kemudian dilakukan uji } \\
\text { laboratorium }\end{array}$ \\
\hline 8 & $\begin{array}{l}\text { Rata-Rata Temperatur dan } \\
\text { curah hujan }\end{array}$ & Sekunder & $\begin{array}{l}\text { Data temperatur periode } 2008-2016 \text { dan } \\
\text { curah hujan periode } 2009-2018\end{array}$ \\
\hline
\end{tabular}




\subsection{Pengolahan dan Analisis Data}

Metode yang digunakan pada penelitian adalah metode matching atau perbandingan yang bertujuan untuk membandingkan kondisi lahan dilapangan dengan kriteria atau syarat tumbuh tanaman durian yang mengacu pada Balai Besar Penelitian dan Pengembangan Sumber Daya Lahan Pertanian (BBSDLP) tahun 2011. Penelitian ini menggunakan satuan lahan sebagai populasi dan setiap satuan lahan diambil 2 sampel dengan random sampling ditempat yang berbeda namun memiliki satuan lahan yang sama, untuk menghindari terjadinya kesalahan pada data, apabila hanya mengambil satu sampel. Satuan lahan di Kecamatan Aranio didapat dari hasil overlay peta dengan menggunakan sistem informasi geografi. Peta yang dioverlay adalah peta penggunaan lahan, peta jenis tanah, peta geologi, peta bentuk lahan dan peta kemiringan lereng yang masing-masing skalanya 1:250.000 didapat dari Badan Perencanaan Pembangunan Daerah Kabupaten Banjar tahun 2019, peta dapat dilihat pada Lampiran 1-5. Peta satuan lahan Kecamatan Aranio disajikan pada Gambar 2.

Data penelitian diambil dengan cara observasi lapangan, uji laboratorium dan pengumpulan data sekunder, kemudian ditabulasikan dan dicocokkan dengan persyaratan tumbuh tanaman durian. Hasil penilaian berupa kelas dan subkelas kesesuaian lahan. Kelas dan subkelas kesesuaian lahan ditentukan dari faktor pembatas terberat. Pembatas lahan dapat terdiri dari satu atau lebih karakteristik lahan.

\section{Hasil dan Pembahasan}

\subsection{Tingkat Kesesuaian Lahan untuk Tanaman Durian di Kecamatan Aranio}

Kecamatan Aranio memiliki 12 satuan lahan yang didapat dari hasil overlay peta kemiringan lereng, peta jenis tanah, peta geologi, peta bentuk lahan, peta penggunaan lahan yang masing-masing skalanya 1:100.000. Satuan di Kecamatan Aranio disajikan pada Tabel 2 dan peta satuan lahan disajikan pada Gambar 2. Karakteristik lahan di Kecamatan Aranio yang didapatkan dari hasil observasi lapangan, pengumpulan data sekunder dan uji laboratorium yaitu sebagai berikut:

a. Temperatur

Tanaman durian cocok tumbuh pada temperatur rata-rata $25-28{ }^{\circ} \mathrm{C}$ dan tidak cocok tumbuh pada temperatur rata-rata $>35{ }^{\circ} \mathrm{C}$ dan $<20^{\circ} \mathrm{C}$ (Balai Besar Penelitian dan Pengembangan Sumber Daya Lahan Pertanian, 2011). Temperatur rata-rata tahunan di Kecamatan Aranio periode tahun 2008-2016

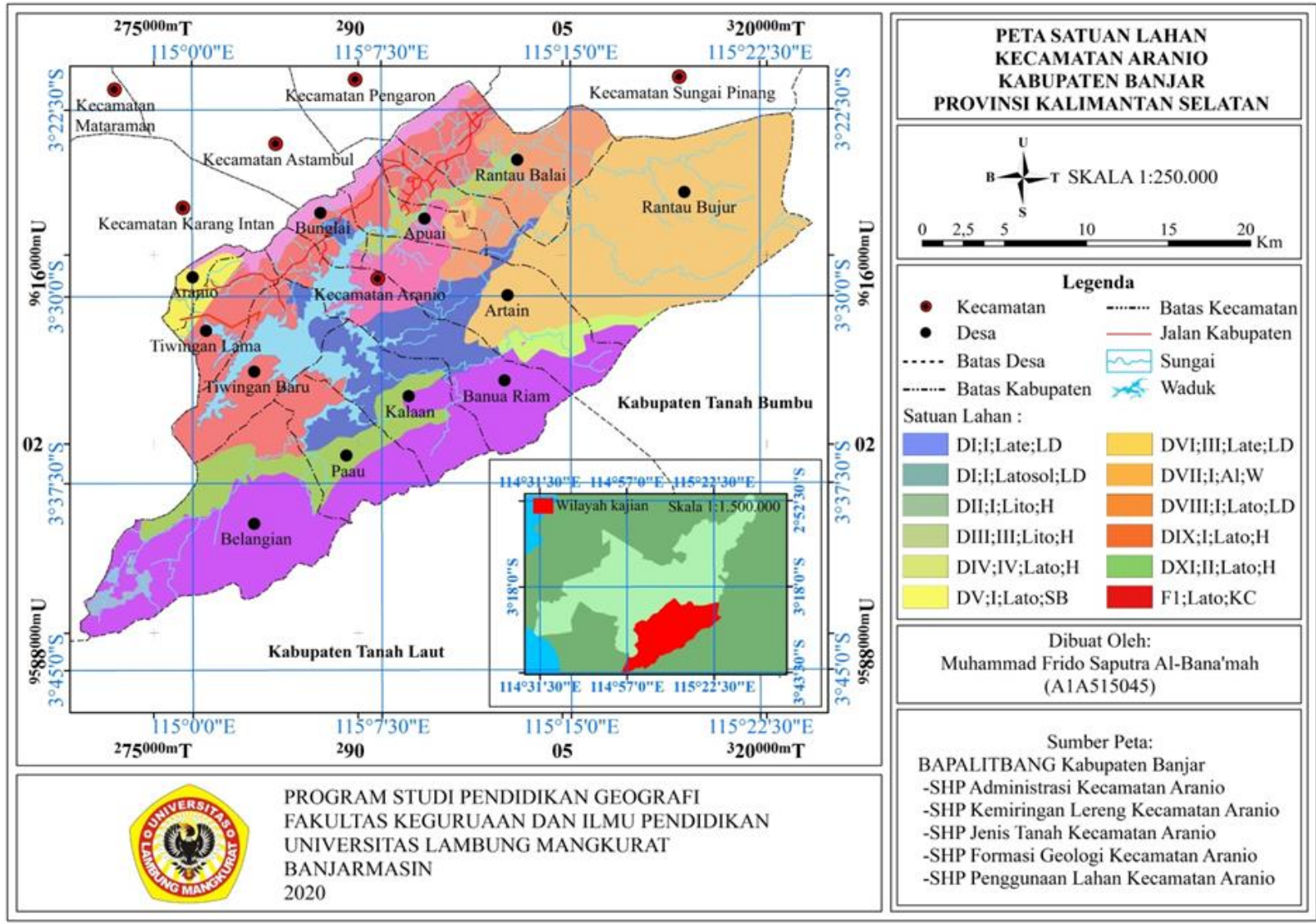

Gambar 2. Peta satuan lahan di Kecamatan Aranio 
Tabel 2. Satuan lahan di Kecamatan Aranio

\begin{tabular}{|c|c|c|}
\hline No & Satuan lahan & Kode satuan lahan \\
\hline 1 & $\begin{array}{l}\text { Pegunungan Terkikis (D I); Lereng 0-8\% (I); Jenis Tanah Laterik (Lt); } \\
\text { Penggunaan Lahan Ladang (LD) }\end{array}$ & DI I Lt LD \\
\hline 2 & $\begin{array}{l}\text { Pegunungan Terkikis (D I); Lereng 0-8\% (I); Jenis Tanah Latosol (La); } \\
\text { Penggunaan Lahan Ladang (LD) }\end{array}$ & DI I La LD \\
\hline 3 & $\begin{array}{l}\text { Perbukitan Terkikis (D2); Lereng 0-8\% (I); Jenis Tanah Litosol (Li); } \\
\text { Penggunaan Lahan Hutan (H) }\end{array}$ & DII I Li H \\
\hline 4 & $\begin{array}{l}\text { Bukit Sisa (D3); Lereng 15-25\% (III); Jenis Tanah Litosol (Li); } \\
\text { Penggunaan Lahan Hutan (H) }\end{array}$ & DIII III Li H \\
\hline 5 & $\begin{array}{l}\text { Dataran Nyaris (D5); Lereng 0-8\% (I); Jenis Tanah Latosol (La); } \\
\text { Penggunaan Lahan Semak Belukar (SB) }\end{array}$ & DV I La SB \\
\hline 6 & $\begin{array}{l}\text { Kaki Lereng (D6); Lereng 15-25\% (III); Jenis Tanah Laterik (Lt); } \\
\text { Penggunaan Lahan Ladang (LD) }\end{array}$ & DVI III Lt LD \\
\hline 7 & $\begin{array}{l}\text { Kaki Lereng (D6); Lereng 0-8\% (I); Jenis Tanah Aluvial (Al); } \\
\text { Penggunaan Lahan Waduk (W) }\end{array}$ & DVI I Al W \\
\hline 8 & $\begin{array}{l}\text { Kipas Rombakan Lereng (D7); Lereng 25-40\% (IV); Jenis Tanah } \\
\text { Latosol (La); Penggunaan Lahan Hutan (H) }\end{array}$ & DVII IV La H \\
\hline 9 & $\begin{array}{l}\text { Gawir (D8); Lereng 0-8\% (I); Jenis Tanah Latosol (La); Penggunaan } \\
\text { Lahan Ladang (LD) }\end{array}$ & DVIII I La LD \\
\hline 10 & $\begin{array}{l}\text { Lahan Rusak (D9); Lereng 0-8\% (I); Jenis Tanah Latosol (La); } \\
\text { Penggunaan Lahan Hutan (H) }\end{array}$ & DIX I La H \\
\hline 11 & $\begin{array}{l}\text { Kipas Rombakan Lereng (D11); Lereng 8-15\% (II); Jenis Tanah } \\
\text { Latosol (La); Penggunaan Lahan Hutan (H) }\end{array}$ & DXI II La H \\
\hline 12 & $\begin{array}{l}\text { Dataran Alluvial (F1); Lereng 0-8\% (I); Jenis Tanah Latosol (La); } \\
\text { Penggunaan Lahan Kebun Campuran (KC) }\end{array}$ & FI I La KC \\
\hline
\end{tabular}

berdasarkan data yang didapat dari BMKG stasiun Kota Banjarbaru adalah $26,99{ }^{\circ} \mathrm{C} /$ tahun. Keadaan rerata temperatur tertinggi di Kecamatan Aranio terjadi pada bulan Mei yaitu $27^{\circ} \mathrm{C}$ dan rerata terendah terjadi pada bulan juli yaitu $26,39{ }^{\circ} \mathrm{C}$, sehingga Kecamatan Aranio memiliki temperatur yang sesuai (S1) dengan kriteria tumbuh tanaman durian.

b. Curah hujan

Tanaman durian dapat tumbuh dan berkembang maksimal jika daerah tempat tumbuhnya memiliki curah hujan antara 2.000-3.000 mm/tahun dan tidak cocok tumbuh jika curah hujan $<1.250$ $\mathrm{mm} /$ tahun dan $>4.000 \mathrm{~mm} /$ tahun (Balai Besar Penelitian dan Pengembangan Sumber Daya Lahan Pertanian, 2011). Rerata curah hujan periode tahun 2009-2018 di Kecamatan Aranio berdasarkan data yang didapat dari BMKG stasiun Kota Banjarbaru adalah $2378 \mathrm{~mm} /$ tahun. Keadaan rerata curah hujan tertinggi di Kecamatan Aranio terjadi pada bulan Desember yaitu 332,36 mm dan rerata terendah terjadi pada bulan Agustus yaitu 51,38 mm, sehingga Kecamatan Aranio memiliki rerata curah hujan yang sesuai (S1) dengan kriteria tumbuh tanaman durian.

\section{c. Tekstur}

Tekstur merupakan komposisi partikel tanah halus (diameter $2 \mathrm{~mm}$ ) yaitu pasir, debu dan liat (Siswanto, 2006). Pengambilan sampel tekstur diambil pada kedalaman lapisan tanah atas $(0-30 \mathrm{~cm})$, hasil tekstur tanah dari laboratorium lalu dicocokkan dengan diagram segitiga tekstur tanah dari sistem USDA. Tekstur tanah yang sangat sesuai (S1) untuk tanaman durian adalah halus, agak halus dan sedang, sementara tekstur tanah yang tidak cocok untuk tanaman durian adalah kasar (Balai Besar Penelitian dan Pengembangan Sumber Daya Lahan Pertanian, 2011).Tekstur tanah di Kecamatan Aranio ada 3 yaitu lempung liat berpasir, lempung berliat dan liat. Semua sampel satuan lahan di Kecamatan Aranio memiliki tekstur tanah yang sangat sesuai (S1) untuk tanaman durian karena tergolong kedalam klasifikasi tekstur halus dan agak halus.

\section{d. Kedalaman efektif tanah}

Kedalaman tanah sangat menentukan pertumbuhan tanaman karena tanah yang dangkal akan terbatas kemampuannya dalam menyediakan air dan unsur hara lainnya. Selain itu juga sangat menentukan lahan bisa diolah atau tidak. Pengelolaan tanah yang dangkal justru akan membalik sub 
soil ke atas yang berakibat terganggunya pertumbuhan tanaman (Siswanto, 2006).Kedalaman efektif tanah dapat ditentukan dengan pengamatan pada sebaran akar tanaman karena pada lapisan batuan keras akar tanaman tidak bisa menembus (Hardjowigeno \& Widiatmaka, 2011).

Kedalaman tanah yang sangat sesuai untuk tanaman durian adalah $>100 \mathrm{~cm}$ dan tidak cocok tumbuh $<50 \mathrm{~cm}$ (Balai Besar Penelitian dan Pengembangan Sumber Daya Lahan Pertanian, 2011). Kedalaman efektif tanah di Kecamatan Aranio untuk tanaman durian ada 3 kelas kesesuaian yaitu S1 dengan kedalaman $>100 \mathrm{~cm}$ berjumlah 4 satuan lahan yaitu lahan DI I La LD, DVIII I La LD, DIX I La H dan FI I La KC. Kelas kesesuaian S2 dengan kedalaman 75-100 cm berjumlah 5 satuan lahan yaitu lahan DI I Lt LD, DII I Li H, DVI III Lt LD, DVII IV La H dan DXI II La H. Kelas kesesuaian N1 dengan kedalaman $<50 \mathrm{~cm}$ berjumlah 1 satuan lahan yaitu lahan DV I La SB.

e. KTK

Kapasitas tukar kation (KTK) menggambarkan jumlah atau besarnya kation yang dapat dipertukarkan atau banyaknya kation (dalam miliequivalen) yang diserap oleh tanah per satuan berat tanah (biasanya per 100 gram tanah), semakin besar nilai KTK maka akan semakin banyak kation yang dapat dipertukarkan sehingga ketersediaan hara tanaman akan semakin meningkat (me/100g) (Siswanto, 2006).

Tanaman durian dapat tumbuh baik atau sesuai (S1) jika KTKnya $>16$ (mg/100g) (Balai Besar Penelitian dan Pengembangan Sumber Daya Lahan Pertanian, 2011).Kandungan kapasitas tukar kation atau KTK pada semua sampel satuan lahan di Kecamatan Aranio menunjukkan angka lebih dari 16 (mg/100g), sehingga semua satuan lahan di Kecamatan Aranio sangat sesuai (S1) untuk tanaman durian.

f. $\mathrm{pH}$

$\mathrm{pH}$ tanah adalah tingkat keasaman pada suatu benda yang diukur dengan skala $\mathrm{pH}$. Parameter $\mathrm{pH}$ merupakan faktor yang dinamis, namun tetap diperlukan dalam kaitannya dengan pengelolaan lahan (Siswanto, 2006). Tanaman durian dapat tumbuh baik atau sesuai (S1) jika $\mathrm{pH}$ tanahnya5,5- 7,8 dan kurang cocok jika $\mathrm{pH}$ tanahnya $>8,0$ dan $<5,0$ (Balai Besar Penelitian dan Pengembangan Sumber Daya Lahan Pertanian, 2011).

pH tanah di Kecamatan Aranio ada 3 kelas kesesuaian yaitu kelas kesesuaian S1 dengan pH 5,5-7,8 berjumlah 4 satuan lahan yaitu lahan DI I Lt LD, DVI III Lt LD, DIX I La H dan DXI II La H. Kelas kesesuaian S2 dengan $\mathrm{pH}<7,8-8,0$ dan 5,0-5,5 berjumlah 4 yaitu lahan DI I La LD, DII I Li H, DVII IV La $\mathrm{H}$ dan FI I La KC. Kelas kesesuaian S3 dengan $\mathrm{pH}>8,0$ dan $<5,0$ berjumlah 2 satuan lahan yaitu lahan DV I La SB dan DVIII I La LD.

\section{g. C-Organik}

Bahan organik (BO/C-org) menunjukkan besarnya kandungan bahan organik tanah. Semakin banyak BO maka struktur tanah akan semakin baik dan akan mempengaruhi KTK dan sebaliknya apabila tanah kekurangan bahan organik dapat mengakibatkan pertumbuhan tanaman kurang maksimal dan tanah kurang subur. Sampel bahan organik diambil pada kedalaman tanah 0-30 cm dan sampel di teliti di laboratorium. Tanaman durian sangat sesuai (S1) tumbuh di lahan yang memiliki Corganik $>1,2 \%$ dan kurang cocok jika $<0,8 \%$ (Balai Besar Penelitian dan Pengembangan Sumber Daya Lahan Pertanian, 2011).

Kandungan C-organik di Kecamatan Aranio ada 2 kelas kesesuaian yaitu S1 dengan klasifikasi $>1,2 \%$ berjumlah 8 satuan lahan yaitu lahan DI I Lt LD, DI I La LD, DII I Li H, DVI III Lt LD, DVII IV La H, DVIII I La LD, DXI II La H dan FI I La KC. Kelas kesesuaian S2 dengan klasifikasi 0,81,2\% berjumlah 2 satuan lahan yaitu lahan DV I La SB dan DIX I La H

\section{h. Kandungan N-total}

N-total mencerminkan potensi kandungan nitrogen dalam tanah yang dapat diserap tanaman. Semakin tinggi kandungan. N-total tanah cenderung memberikan pengaruh baik pada pertumbuhan tanaman. Tanaman durian sangat sesuai (S1) tumbuh di lahan yang mempunyai N-total klasifikasi sedang dan kurang cocok jika termasuk klasifikasi sangat rendah. Kandungan Nitrogen Total dalam tanah pengukurannya dilakukan di laboratorium dan dinyatakan dalam persen (Balai Besar Penelitian dan Pengembangan Sumber Daya Lahan Pertanian, 2011).

Kandungan N-total di Kecamatan Aranio ada 3 klasifikasi yaitu klasifikasi sangat rendah $(<0,10 \%)$ berjumlah 1 satuna lahan yaitu lahan DIX I La $\mathrm{H}$ yang termasuk keadalam kelas kesesuaian S3, rendah $(0,10 \%-0,20 \%)$ berjumlah 4 satuan lahan yaitu lahan DI I Lt LD, DI I La LD, DII I Li H dan FI I La KC yang termasuk kedalam kelas kesesuaian S2 dan sedang $(0,21 \%-50 \%)$ berjumlah 5 satuan lahan 
yaitu lahan DV I La SB, DVI III Lt LD, DVII IV La H, DVIII I La LD dan DXI II La H yang termasuk kedalam kelas kesesuaian S1.

i. $\mathrm{P}_{2} \mathrm{O}_{5}$

Kandungan Phospat $\left(\mathrm{P}_{2} \mathrm{O}_{5}\right)$ merupakan unsur berperan dalam transefer energi. Kandungan phospat tersedia dalam bentuk ion $\mathrm{P}_{2} \mathrm{O}_{5}$ yang pengukurannya dilakukan di laboratorium dan dinyatakan dalam bentuk HCL 25\% (mg/100gr). Tanaman durian sangat sesuai (S1) tumbuh di lahan yang mempunyai $\mathrm{P}_{2} \mathrm{O}_{5}$ klasifikasi sedang dan kurang cocok jika termasuk klasifikasi sangat rendah (Balai Besar Penelitian dan Pengembangan Sumber Daya Lahan Pertanian, 2011).

Kandungan $\mathrm{P}_{2} \mathrm{O}_{5}$ di Kecamatan Aranio terdapat 3 klasifikasi yaitu klasifikasi sangat rendah $(<15$ mg/100g) berjumlah 4 satuan lahan yaitu lahan DV I La SB, DVI III Lt LD, DIX I La H dan FI I La KC yang termasuk kedalam kelas kesesuaian S3, rendah (15-20 mg/100g) berjumlah 2 satuan lahan yaitu lahan DVIII I La LD dan DXI II La H yang termasuk kedalam kelas kesesuaian S2, sedang (21$40 \mathrm{mg} / 100 \mathrm{~g})$ dan tinggi $(41-60 \mathrm{mg} / 100 \mathrm{~g})$ berjumlah 4 satuan lahan yaitu lahan DI I Lt LD, DI I La LD, DII I Li H dan DVII IV La H yang termasuk kedalam kelas kesesuaian S1.

j. $\mathrm{K}_{2} \mathrm{O}$

Kalium mempunyai fungsi dalam proses fisiologi tanaman dan proses metabolisme pada tanaman. Kalium mempunyai pengaruh terhadap absorbi hara, pengarturan pernapasan, transpirasi, kerja enzim dan berfungsi translokasi karbohidrat (Hakim, 1986). Kalium diukur di laboratorium dalam satuan me/100 gr. Tanaman durian sangat sesuai (S1) tumbuh di lahan yang mempunyai K-total klasifikasi sedang dan kurang cocok jika termasuk klasifikasi sangat rendah (Balai Besar Penelitian dan Pengembangan Sumber Daya Lahan Pertanian, 2011).

Kandungan kadar kalium di Kecamatan Aranio terdapat 3 klasifikasi yaitu klasifikasi sangat rendah ( $<10 \mathrm{mg} / 100 \mathrm{~g}$ ) berjumlah 2 satuan lahan yaitu lahan DVI III Lt LD dan DV I La SB yang termasuk kedalam kelas kesesuaian S3, rendah $(10-20 \mathrm{mg} / 100 \mathrm{~g})$ berjumlah 2 satuan lahan yaitu lahan DI I Lt LD dan DIX I La H yang termasuk kedalam kelas kesesuaian S2 dan sedang (21-40 mg/100g) berjumlah 6 satuan lahan yaitu lahan DI I La LD, DII I Li H, DVII IV La H, DVIII I La LD, DXI II La H dan FI I La KC yang termasuk kedalam kelas kesesuaian S1.

k. Tingkat bahaya erosi

Tingkat bahaya erosi menentukan kesesuaian tananaman durian. Tingkat bahaya erosi dapat dilihat dari permukaan tanah yang hilang yang dicirikan oleh sudah terkikisnya horizon A (Ritung et al., 2007). Tanaman durian sangat sesuai (S1) tumbuh di lahan yang mempunyai bahaya erosi sangat rendah dan tidak cocok tumbuh pada lahan yang memiliki bahaya erosi sangat berat (Balai Besar Penelitian dan Pengembangan Sumber Daya Lahan Pertanian, 2011).

Tingkat bahaya erosi di Kecamatan Aranio terdapat 2 klasifikasi yaitu rendah dan sangat rendah. Klasifikasi sangat rendah mendominasi di Kecamatan Aranio, sehingga sesuai (S1) untuk pertumbuhan dan perkembangan tanaman durian yang terdapat pada satuan lahan DI I Lt LD, DV I La SB, DVII IV La H, DIX I La H, DXI II La H dan FI I La KC. Klasifikasi bahaya erosi sedang, cukup sesuai (S2) untuk tanaman durian, sehingga perlu ada peningkatan kualitas lahan yang terdapat pada satuan lahan DI I La LD, DII I Li H, DVI III Lt LD dan DVIII I La LD.

1. Kemiringan lereng

Sudut yang dibentuk dengan adanya perbedaan tinggi permukaan lahan disebut dengan kemiringan lereng yang dinyatakan dalam satuan persen (\%). Kemiringan lereng diukur langsung dilapangan dengan menggunakan abney level dan yalon. Tanaman durian sangat sesuai (S1) tumbuh di lahan yang mempunyai kemiringan lereng $<8 \%$ dan tidak cocok tumbuh pada lereng yang mempunya kemiringan $>30 \%$ (Balai Besar Penelitian dan Pengembangan Sumber Daya Lahan Pertanian, 2011).

Kemiringan lereng di Kecamatan Aranio ada 3 kelas kesesuaian yaitu S1 dengan klasifikasi < $8 \%$ berjumlah 4 satuan lahan yaitu lahan DVII IV La H, DVIII I La LD, DIX I La H dan DXI II La H. Klasifikasi kesesuaian S2 dengan klasifikasi 8-16\% berjumlah 4 satuan lahan yaitu lahan DI I La LD, DII I Li H, DV I La SB dan FI I La KC. Kelas kesesuaian S3 dengan klasifikasi 16-30\% berjumlah 2 satuan lahan yaitu lahan DI I Lt LD DVI III Lt LD.

m. Bahaya Banjir

Bahaya banjir ditentukan oleh adanya pengaruh dari kedalaman banjir dan lamanya banjir. Data kedalaman banjir dan lamanya banjir diperoleh melalui wawancara di lapangan. Tanaman durian sangat sesuai (S1) berada pada lahan F(0) yaitu klasifikasi tidak ada banjir (Balai Besar Penelitian dan Pengembangan Sumber Daya Lahan Pertanian, 2011). 
Tabel 3. Kelas kesesuaian lahan tanaman durian di Kecamatan Aranio

\begin{tabular}{llll}
\hline No & Satuan Lahan & Kelas & Faktor pembatas \\
\hline 1 & DI I Lt LD & S3 & Lereng \\
2 & DI I La LD & S2 & Lereng, bahaya erosi, N-total,pH \\
3 & DII I Li H & S2 & Lereng, bahaya erosi, N-total, pH, kedalaman tanah \\
4 & DIII III Li H & Tidak ada sampel & - \\
5 & DV I La SB & N1 & Kedalaman tanah \\
6 & DVI III Lt LD & S3 & Lereng, K-total, P-total \\
7 & DVI I Al W & Tidak ada sampel & - \\
8 & DVII IV La H & S2 & Batuan permukaan, Ph, kedalaman tanah \\
9 & DVIII I La LD & S3 & pH \\
10 & DIX I La H & S3 & Kejenuhan Basa, P-total, N-total \\
11 & DXI II La H & S2 & P-total, kejenuhan basa, kedalaman tanah \\
12 & FI I La KC & N1 & Bahaya banjir \\
\hline
\end{tabular}

Bahaya Banjir di Kecamatan aranio dari hasil wawancara dengan beberapa masyarakat sekitar di sekitar satuan lahan terdapat 2 klasifikasi yaitu tidak ada banjir (F0) dan kelas bahaya banjir ringan (F1). Bahaya banjir di Kecamatan Aranio di dominasi klasifikasi tidak ada (F0) karena letak Kecamatan Aranio merupakan dataran-dataran tinggi dan masih banyak terdapat hutan lindung, sehingga sangat sesuai (S1) untuk pertumbuhan dan perkembangan tanaman durian, namun masih ada satu satuan lahan yang memiliki potensi banjir klasifikasi ringan yang terdapat pada satuan lahan FI I La KC yang merupakan bentuk lahan aluvial. Potensi banjir di satuan lahan FI I La KC sangat jarang terjadi dan hanya berupa genangan kecil dan tidak berlangsung lama.

n. Batuan Permukaan

Batuan Permukaan adalah volume batuan (dalam \%) yang ada di permukaan tanah. Pengukuran batuan permukaan dapat dilakukan dengan membuat grid dengan ukuran $1 \mathrm{~m}^{2}$ sebagai sampel untuk lahan tersebut setelah itu lakukan pengamatan pada grid tersebut sesuai dengan persebaran batuan pada lahan. Tanah yang mempunyai banyak batuan permukaan tidak sulit dilakikan pengelolaan tanah. Tanaman durian sangat cocok tumbuh pada lahan yang memiliki batuan permukaan $<5 \%$ dan tidak cocok tumbuh pada lahan yang memiliki batuan permukaan $>40 \%$ (Balai Besar Penelitian dan Pengembangan Sumber Daya Lahan Pertanian, 2011).

Batuan permukaan di Kecamatan Aranio terdapat 2 kelas kesesuaian yaitu S1 dengan klasifikasi $<5 \%$ berjumlah 9 satuan lahan yaitu lahan DI I Lt LD, DI I La LD, DII I Li H, DV I La SB, DVI III Lt LD, DVIII I La LD, DIX I La H, DXI II La H dan FI I La KC. Kelas kesesuaian S2 dengan klasifikasi 5-15\% berjumlah 1 satuan lahan yaitu lahan DVII IV La $\mathrm{H}$.

o. Singkapan batuan

Singkapan batuan adalah volume batuan (dalam \%) yang ada dalam solum tanah yang tersingkap, sehingga terlihat di permukaan tanah yang diakibatkan oleh erosi (Siswanto, 2006). Pengukuran singkapan batuan dapat dilakukan dengan membuat grid dengan ukuran $1 \mathrm{~m}^{2}$ sebagai sampel untuk lahan tersebut setelah itu lakukan pengamatan pada grid tersebut sesuai dengan persebaran singkapan batuan pada lahan. Tanaman durian sangat cocok tumbuh pada lahan yang memiliki singkapan batuan $<5 \%$ dan tidak cocok tumbuh pada lahan yang memiliki singkapan batuan $>25 \%$ (Balai Besar Penelitian dan Pengembangan Sumber Daya Lahan Pertanian, 2011).

Singkapan batuan di Kecamatan Aranio ada 2 kelas kesesuaian yaitu S1 dengan klasifikasi <5\% berjumlah 9 satuan lahan yaitu lahan DI I Lt LD, DI I La LD, DII I Li H, DV I La SB, DVI III Lt LD, DVII IV La H, DVIII I La LD, DXI II La H dan FI I La KC. Kelas kesesuaian S2 dengan klasifikasi 5$15 \%$ berjumlah 1 satuan lahan yaitu lahan DIX I La H

\subsection{Faktor Pembatas Kesesuaian Lahan untuk Tanaman Durian di Kecamatan Aranio}

Hasil matching (mencocokan) dengan syarat tumbuh tanaman durian di dapat kelas kesesuaian lahan tanaman durian dan faktor pembatasnya untuk setiap satuan lahan di Kecamatan Aranio yang disajikan pada Tabel 3. Klasifikasi kelas kesesuaian lahan untuk tanaman durian ada 3 yaitu S2(cukup sesuai) berjumlah 4 satuan lahan, S3 (sesuai marginal) berjumlah 4 satuan lahan, N1(tidak sesuai saat ini) berjumlah 2 dan ada 2 satuan lahan yang tidak bisa diambil sampel pada satuan lahan DIII III Li H 


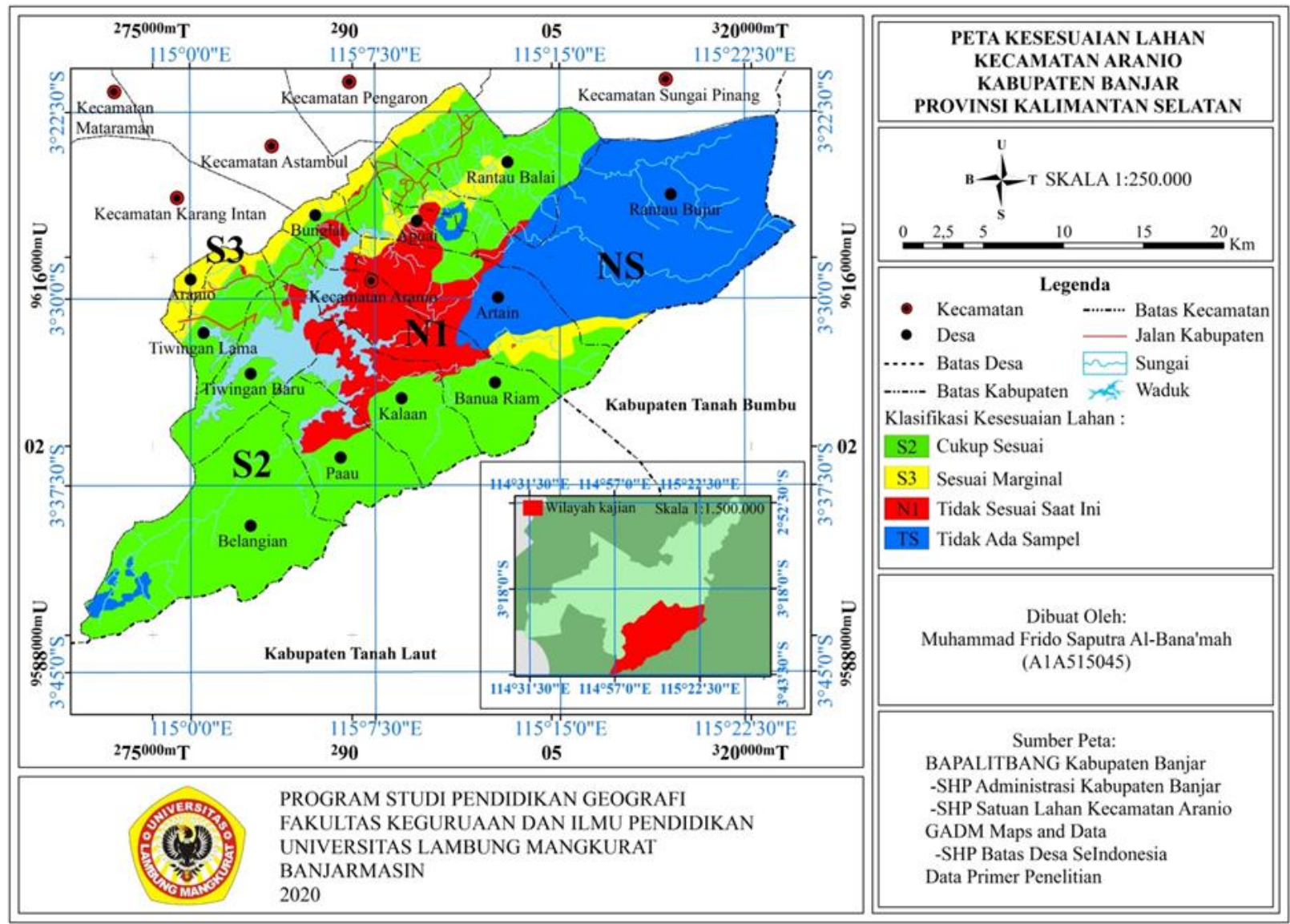

Gambar 3. Peta kesesuaian lahan untuk tanaman durian di Kecamatan Aranio

(satuan lahan 4) dan DVI I Al W (satuan lahan 7) karena tidak ada akses menuju kelokasi sampel penelitian (Tabel 3).

Kelas kesesuaian lahan S2(cukup sesuai) dengan luas 15069,68 ha memiliki faktor pembatas berupa lereng, bahaya erosi, N-total, $\mathrm{pH}$, P-total, kejenuhan basa, kedalaman tanah dan batuan permukaan yang terdapat pada satuan lahan DI I La LD, DII I Li H, DVII IV La H dan DXI II La H. Lahan S2 (cukup sesuai) mempunyai pembatas lahan yang dapat mempengaruhi produktivitas lahan sehingga perlu adanya perbaikan lahan untuk meningkatkan kualitas dari lahan tersebut. Perbaikan biasanya dapat dilakukan oleh petani sendiri (Ritung et al., 2011).

Kelas kesesuaian lahan S3 (sesuai marginal) dengan luas 1485,78 ha mempunyai faktor pembatas berupa lereng, K-total, P-total, N-total, $\mathrm{pH}$ dan kejenuhan basa yang terdapat pada satuan lahan DI I Lt LD, DVI III Lt LD, DVIII I La LD dan DIX I La H. Kelas kesesuaian S3(sesuai marginal) mempunyai faktor pembatas yang berat dan faktor pembatas ini akan berpengaruh terhadap produktivitas atau keuntungan, sehingga memerlukan tambahan masukan yang lebih banyak daripada lahan yang tergolong S2. Mengatasi faktor pembatas pada S3 memerlukan modal tinggi, sehingga perlu adanya bantuan atau campur tangan (intervensi) pemerintah atau pihak swasta. Tanpa bantuan tersebut petani tidak mampu mengatasinya (Ritung et al., 2011).

Kelas kesesuaian lahan N1 (tidak sesuai saat ini) dengan luas 3980.03 mempunyai faktor pembatas berupa bahaya banjir dan kedalaman tanah yang terdapat pada satuan lahan DV I La SB dan FI I La KC. Kelas kesesuaian lahan N1(tidak sesuai saat ini) mempunyai lahan yang tidak sesuai karena mempunyai faktor pembatas yang sangat berat, tetapi sifatnya tidak permanen, dengan tekhnologi dan masukan yang tinggi, secara ekonomis masih memungkinkan untuk diperbaiki dengan mengatasi faktor-faktor pembatasnya (Ritung et al., 2011). Peta kesesuaian lahan untuk tanaman durian disajikan pada Gambar 3 dan table kelas kesesuaian lahan untuk tanaman durian setiap desa di Kecamatan Aranio disajikan pada Tabel 4.

Berdasarkan Tabel 4. Desa di Kecamatan Aranio yang memiliki kelas kesesuaian S2 diatas 50\% yaitu desa Belangian, Benua Riam, Kalaan, Paau, Rantau Balai, Tiwingan Baru dan Tiwingan Lama, namun yang sangat berpotensi untuk dikembangkan adalah desa Tiwingan Baru dan Tiwingan Lama karena memiliki penggunaan lahan semak belukar, ladang dan kebun campuran diatas 50\%, sementara desa Belangian, Benua Riam, Kalaan, Paau dan Rantau Balai memiliki penggunaan lahan didominasi 
Tabel 4. Kesesuaian lahan tanaman durian setiap desa di Kecamatan Aranio

\begin{tabular}{|c|c|c|c|c|c|}
\hline \multirow{2}{*}{ No } & \multirow{2}{*}{ Desa } & \multicolumn{4}{|c|}{ Luas kelas kesesuaian lahan (hektar) } \\
\hline & & $\mathrm{S} 2$ & S3 & $\mathrm{N}$ & Tidak ada sampel \\
\hline 1 & Apuai & $1364.19(45.65 \%)$ & $767.2(25.67 \%)$ & $639.69(21.40 \%)$ & $217.61(7.28 \%)$ \\
\hline 2 & Aranio & - & $985.22(100 \%)$ & - & - \\
\hline 3 & Artain & $2252.11(22.99 \%)$ & $1456.89(14.87 \%)$ & $3051.54(31.15 \%)$ & 3034.37 (30.98\%) \\
\hline 4 & Belangian & $\begin{array}{l}14708.69 \\
(95.63 \%)\end{array}$ & $2.06(0.01 \%)$ & - & $670.46(4.36 \%)$ \\
\hline 5 & Benua Riam & $4815.70(53.28 \%)$ & $289.30(3.20 \%)$ & $3814.41(4.20 \%)$ & $118.63(1.31 \%)$ \\
\hline 6 & Bunglai & $677.93(39.80 \%)$ & $596.95(35.05 \%)$ & $428.32(25.15 \%)$ & - \\
\hline 7 & Kalaan & $4192.41(67.37 \%)$ & - & $2030.33(32.63 \%)$ & - \\
\hline 8 & Paau & $4885.97(85.53 \%)$ & - & $826.78(14.47 \%)$ & - \\
\hline 9 & Rantau Balai & $6735.24(73.82 \%)$ & $1435.89(15.74 \%)$ & $91.54(1 \%)$ & $861.66(9.44 \%)$ \\
\hline 10 & Rantau Bujur & $2601.57(10.67 \%)$ & $859.45(3.52 \%)$ & $313.58(1.29 \%)$ & $20613.78(84.52 \%)$ \\
\hline 11 & Tiwingan Baru & $3680.40(86.93 \%)$ & $0.37(0.01 \%)$ & $577.66(13.57 \%)$ & - \\
\hline 12 & $\begin{array}{l}\text { Tiwingan } \\
\text { Lama }\end{array}$ & $2437.48(72.22 \%)$ & $911.94(27.02 \%)$ & $25.72(0.76 \%)$ & - \\
\hline
\end{tabular}

oleh hutan dan waduk diatas 50\%, sehingga kurang cocok untuk dikembangkan tanaman durian. Tiwingan Baru memiliki penggunaan lahan berupa semak belukar (21.46\%), ladang (46.02\%), kebun campuran $(24.65 \%)$, hutan $(0.48 \%)$, waduk $(7.18 \%)$ dan permukiman $(0.22 \%)$, sementara Tiwingan Lama memiliki penggunaan lahan berupa semak belukar (28.78\%), ladang (21.21\%), kebun campuran $(8.32 \%)$, hutan $(7.47 \%)$, waduk $(34.18 \%)$ dan permukiman $(0.03 \%)$. Tanaman durian jika ingin ditingkatkan kualitas lahannya atau diperbaiki oleh masyarakat, maka dapat dilakukan dengan cara berikut:

a. faktor pembatas $\mathrm{pH}$ tanah dapat ditanggulangi dengan cara pengapuran (kapur tohor, batu kapur, dolomit) untuk menetralkan ion hidrogen $\left(\mathrm{H}^{+}\right)$oleh hidroksida $\left(\mathrm{OH}^{-}\right)$dan sekaligus menambah kandungan kalsium (Ca) dan magnesium (Mg) (Sutanto, 2005).

b. faktor pembatas kemiringan lereng dan bahaya erosi dapat ditanggulangi dengan cara pengolahan dan penanaman sejajar kontur serta melaksanakan konservasi metode mekanik, yaitu pembuatan teras bangku, kredit dan gulud untuk mengontrol limpasan permukaan (Sutanto, 2005).

c. faktor pembatas bahaya banjir dapat ditanggulangi dengan cara pembuatan saluran drainase untuk mempercepat pembuangan air (Ritung et al., 2011), selain itu juga dapat dilakukan penanaman pohon ditempat yang agak tinggi karena disatuan lahan FI I La KC atau bentuk lahan aluvial masih banyak terdapat bukit-bukit, selain itu genangan yang terjadi hanya berupa genangan kecil dan tidak berlangsung lama

d. faktor pembatas batuan batuan permukaan dapat ditanggulangi dengan pengolahan lahan menyingkirkan batuan-batuan permukaan dengan alat seperti garpu rumput, cangkul dan sebagainya.

e. faktor pembatas kimia tanah berupa C-Organik tanah, Phosfat $\left(\mathrm{P}_{2} \mathrm{O}_{5}\right)$, N-total, Kadar Kalium $\left(\mathrm{K}_{2} \mathrm{O}\right)$ dan kejenuhan basa dapat ditanggulangi dengan cara pemberian bahan organik pada lahan seperti pupuk kandang, kompos, atau bisa juga pupuk hijau pada saat pengolahan tanah sebelum dimulai penanaman duriandengan menggunakan dosis dan jadwal yang tepat sesuai dengan kebutuhan tanaman durian sesuai anjuran dari balai atau instansi terkait ( Fikri, 2015)

\section{Kesimpulan}

Kelas Kesesuaian lahan di Kecamatan Aranio terbagi menjadi 3 kelas kesesuaian yaitu S2 (cukup sesuai) dengan luas 15069,68 ha yang bisa dimanfaatkan masyarakat untuk budidaya tanaman durian karena faktor pembatas masih bisa diperbaiki oleh petani, S3 (sesuai marginal) dengan luas 1485,78 ha, mempunyai faktor pembatas yang berat dan mempunyai pengaruh terhadap produktivitas atau keuntungan yang memerlukan biaya perbaikan yang cukup besar, dan N1 (tidak sesuai saat ini) dengan luas 3980,03 ha, dengan pembatas lahan yang sangat berat tetapi sifatnya tidak permanen sehingga masih memungkinkan untuk diperbaiki dengan teknologi tetapi biaya perbaikan lahan yang besar. Lahan N1 tidak dapat direkomendasikan untuk dibudidayakan tanaman durian. Satuan lahan DIII III 
Li H dan DVI I Al W tidak dapat diambil sampel karena tidak ada akses menuju kelokasi sampel, sehingga terdapat 2 satuan lahan yang tidak diketahui kelas kesesuaiannya yang menjadi kekurangan pada penelitian ini dan perlu dilakukan penelitian lebih lanjut, jika akses perjalanan menuju titik sampel bisa dilalui, karena diwaktu penelitian ini dilakukan daerah tersebut masih hutan belantara yang tidak mungkin dilalui. Desa di Kecamatan Aranio yang berpotensi dikembangkan budidaya tanaman durian karena memiliki kelas kesesuaian S2 dan penggunaan lahan berupa semak belukar, ladang dan kebun campuran diatas 50\% yaitu Tiwingan Baru dan Tiwingan Lama.

\section{Ucapan Terima Kasih}

Peneliti mengucapkan rasa terimakasih yang tak terhingga kepada Pemerintah Kabupaten Banjar, Universitas Lambung Mangkurat, masyarakat Kecamatan Aranio dan seluruh rekan-rekan yang membantu peneliti, sehingga penelitian ini dapat terselesaikan.

\section{Referensi}

Achadiah, Elis. (2016). Analisis Kesesuaian Lahan Tanaman Durian di Kecamatan Wonosalam Kabupaten Jombang. Surabaya: Skripsi.

Anggraini, E. T. (2011). Evaluasi Kesesuaian Lahan untuk Tanaman Kopi di Kecamatan Bulu Kabupaten Temanggung. Universitas Negeri Semarang: Skripsi

Arisanty, D., \& Syarifuddin, S. (2018). Evaluasi Kesesuaian Lahan Untuk Tanaman Kelapa Sawit Di Kecamatan Marabahan Kabupaten Barito Kuala. Jurnal Geografi: Media Informasi Pengembangan dan Profesi Kegeografian, 14(2), 27-35.

Badan Pusat Statistik Kabupaten Banjar. (2018). Kecamatan Aranio dalam Angka 2018. ISBN 97860252950-1-0.

Balai Besar Penelitian dan Pengembangan Sumberdaya Lahan Pertanian. (2011). Evaluasi Lahan Untuk Komoditas Pertanian. Bogor: Balai Besar Sumberdaya Lahan Pertanian.

Djaenuddin , D., Marwan, H., Subagjo, H., \& A. Hidayat (2011). Petunjuk Teknis Evaluasi Lahan Untuk Komoditas Pertanian. Bogor: Balai Besar Litbang Sumberdaya Lahan Pertanian, Badan Litbang Pertanian.

Fikri, F. A. (2015). Evaluasi Kesesuaian Lahanuntuk Tanaman Durian (Durio Zibhethinus Murr)di Kecamatan Tonjong Kabupaten Brebes. Yogyakarta: Skripsi.

Hardjowigeno, S. \& Widiatmaka. (2011). Evaluasi Kesesuaian Lahan dan Perencanaan Tataguna Lahan. Yogyakarta: Gajah Mada University Press.

Hakim, N. M. (1986). Dasar-dasar Ilmu Tanah. Lampung: Uniersitas Lampung.

Nugroho, A. B. (2017). Analisis Pemetaan Wilayah Potensi Tanaman Durian Di Kabupaten Wonogiri. Wonogiri: Bappeda dan Litbang Kabupaten Wonogiri.

Pertama, W., \& Syukur. (2014). Jenis durian unggul dan bahan tanam durian. Jambi: Balai Pelatihan Pertanian.

Ritung, S., Wahyunto, Fahmuddin Agus \& Hapid Hidayat. (2007). Panduan Teknis Evaluasi Lahan Dengan Contoh Peta Arahan Penggunaan Lahan di Kecamatan Aceh Barat. Bogor Balai Penelitian Tanah dan World Agroforestry Centre.

Ritung, S., Kusumo Nugroho, Anny Mulyani \& Erna Suryani. (2011). Petunjuk Teknis Evaluasi Lahan Untuk Komoditas Pertanian (edisi Revisi). Bogor : Balai Besar Penelitian dan Pengembangan Sumberdaya Lahan Pertanian, Badan Penelitian dan Pengembangan Pertanian.

Safitri, S. (2015). Evaluasi kesesuaian lahan untuk tanaman Kakao (Theobroma cacao L.) di lahan Politeknik Pertanian Negeri.

Siswanto. (2006). Evaluasi sumberdaya lahan. UPN Press. ISBN 978-979-3100-94-4.

Sitorus, S. R. (1985). Evaluasi Sumberdaya Lahan. Bandung: Tarsito Bandung.

Sutanto, R. (2005). Dasar-Dasar Ilmu Tanah.Yogyakarta: KANISIUS. ISBN 978-979-21-0467-7.

Takliviyah, L. (2016). Kajian Kesesuaian Lahan untuk Tanaman Durian (Durio Zibethinus Murr.) di Kebun Buah Mangunan Kecamatan Dlingo Kabupaten Bantul. Yogyakarta: Skripsi.

Tim Agro Mandiri. (2016). Tips Sukses Budidaya Durian Unggul. Surakarta: Visi Mandiri. ISBN 978-602317-246-7. 


\section{Lampiran}

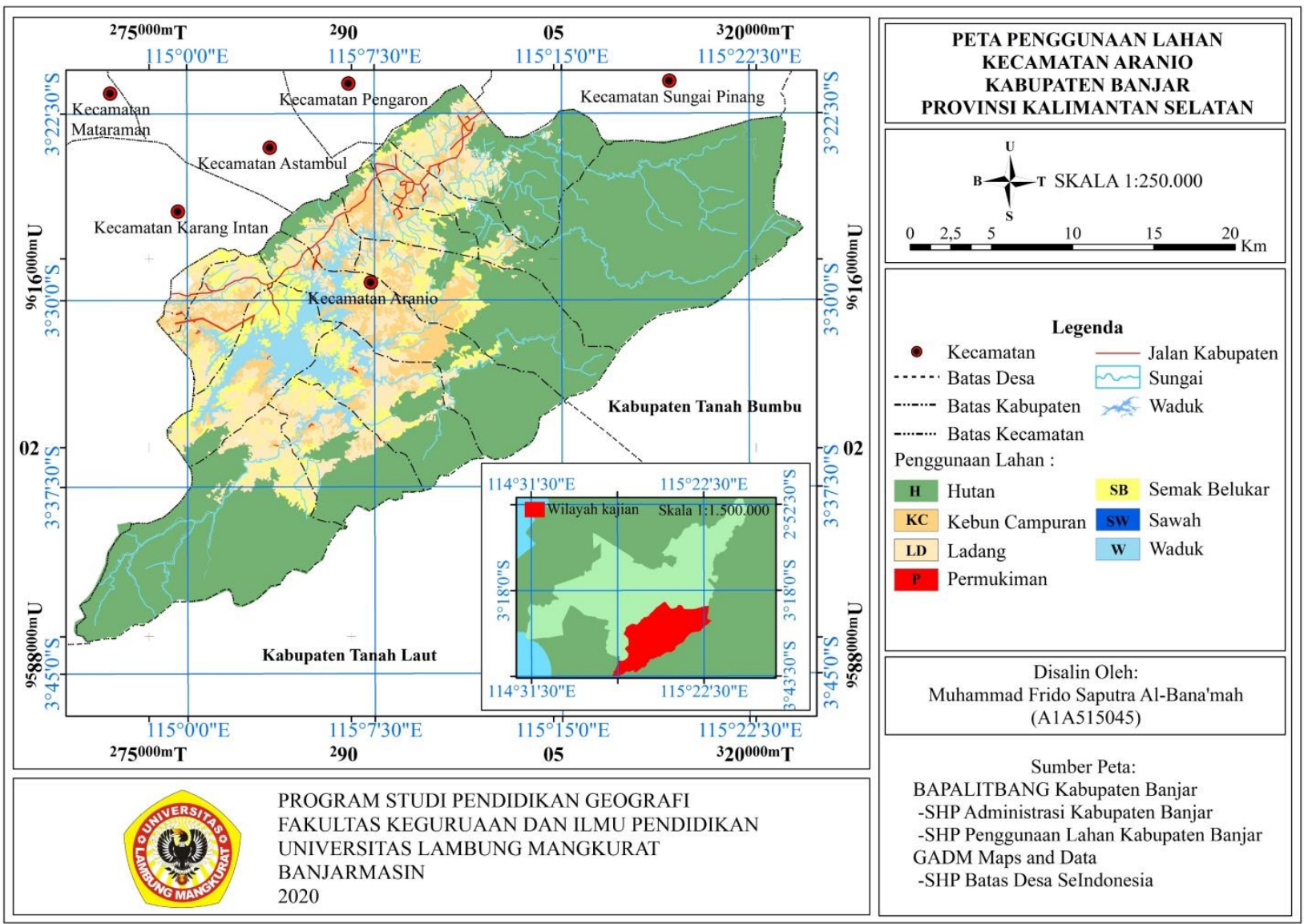

Lampiran 1. Peta penggunaan lahan di Kecamatan Aranio

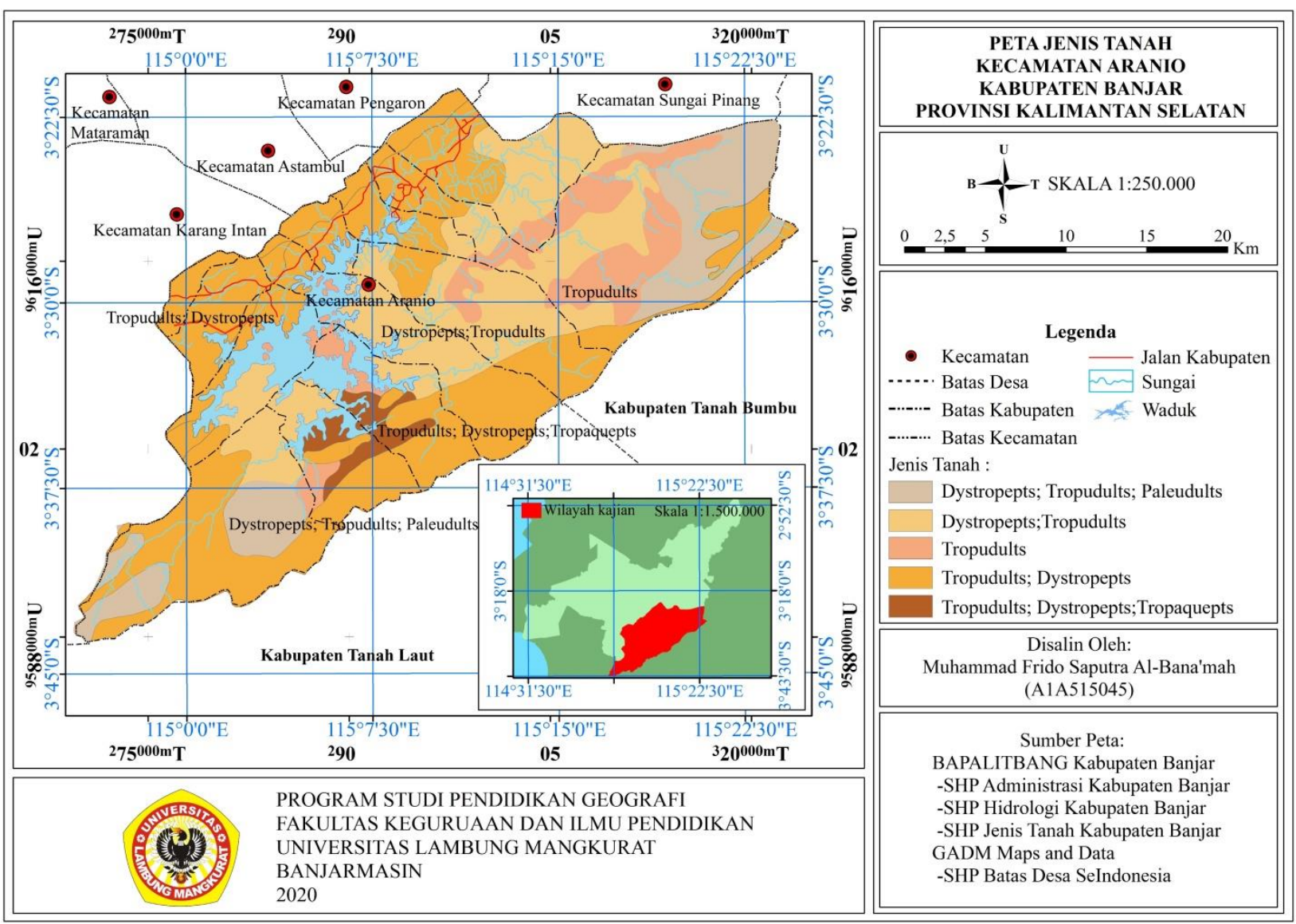

Lampiran 2. Peta jenis tanah di Kecamatan Aranio 


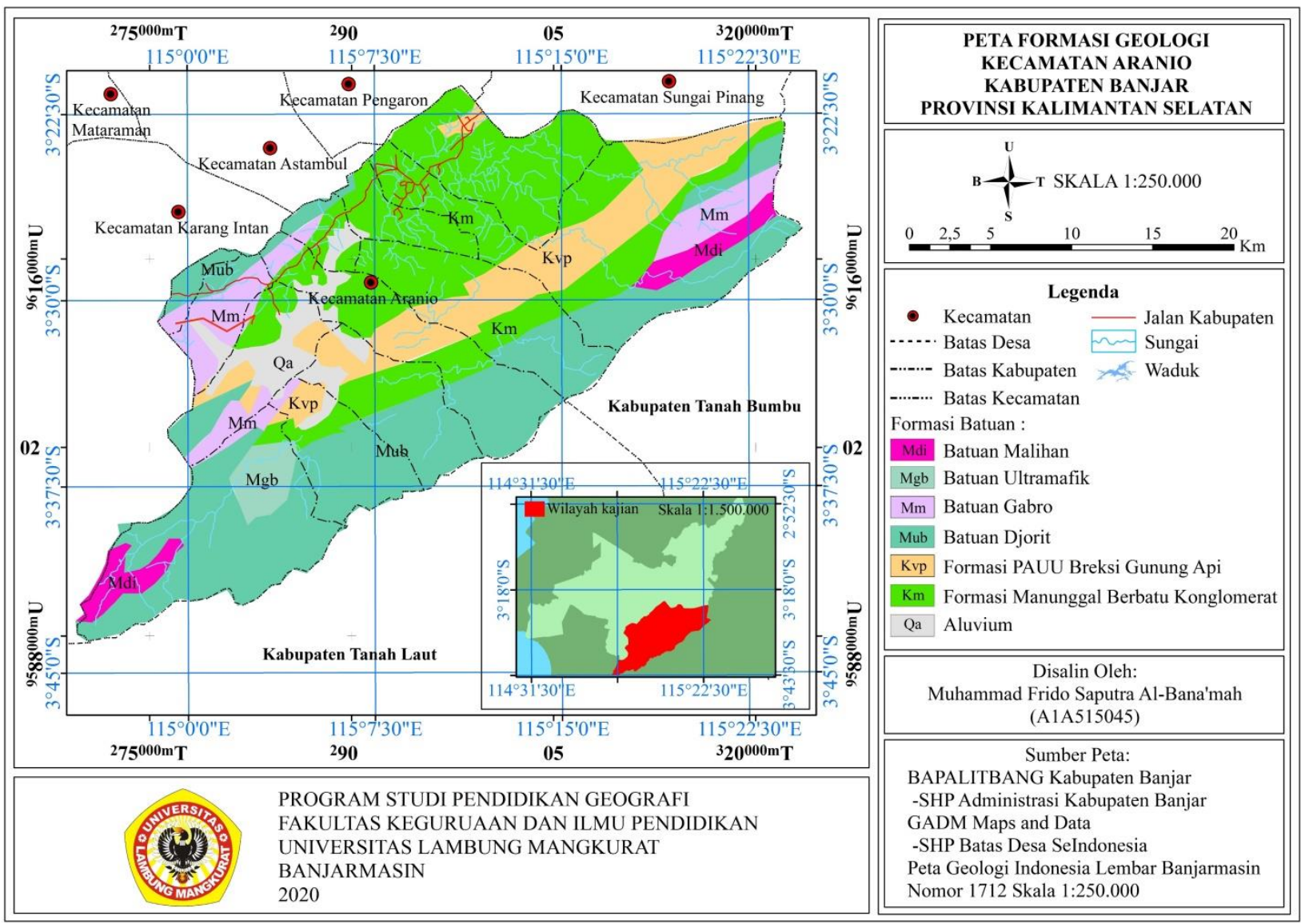

Lampiran 3. Peta formasi geologi di Kecamatan Aranio

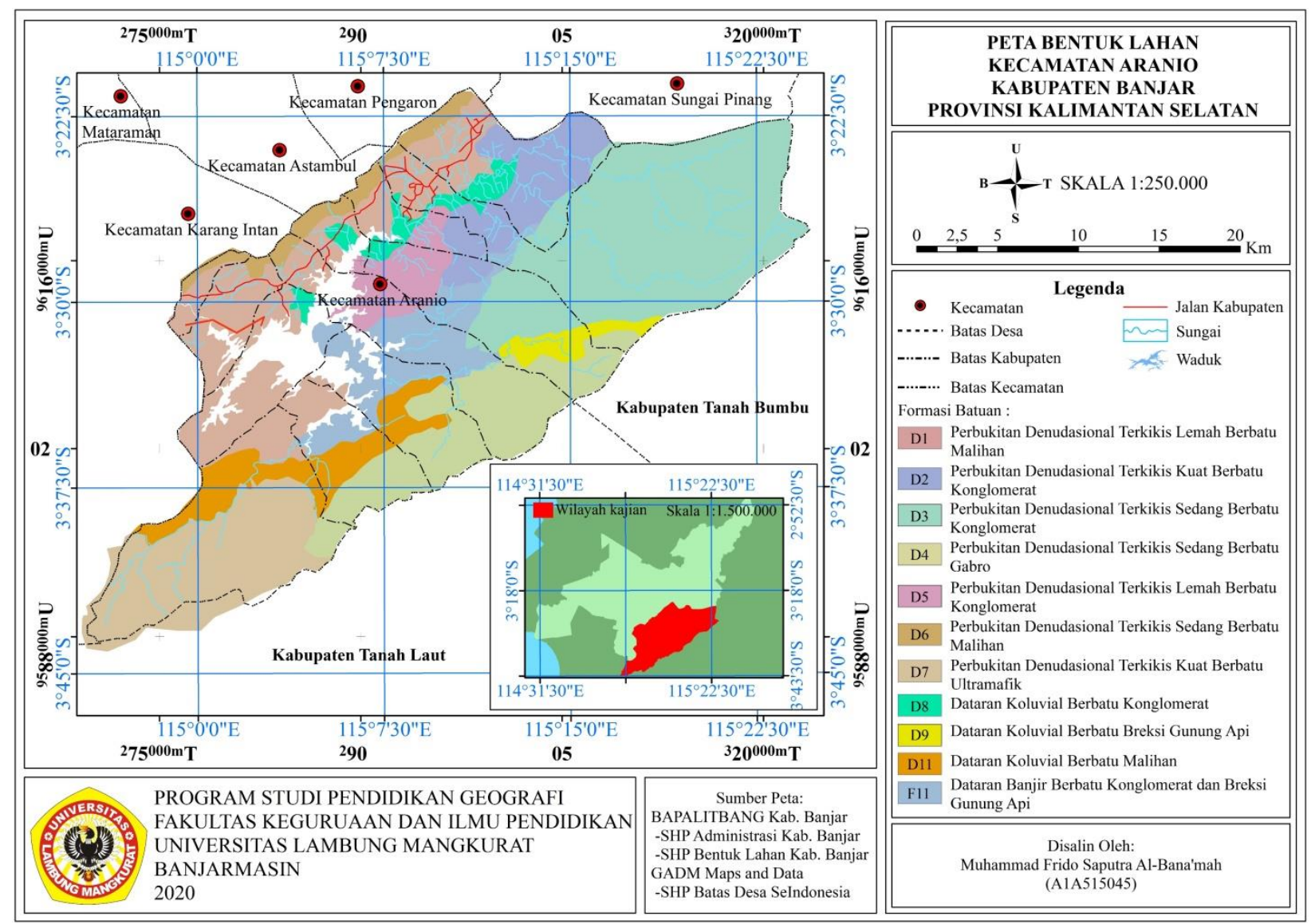

Lampiran 4. Peta bentuk lahan di Kecamatan Aranio 


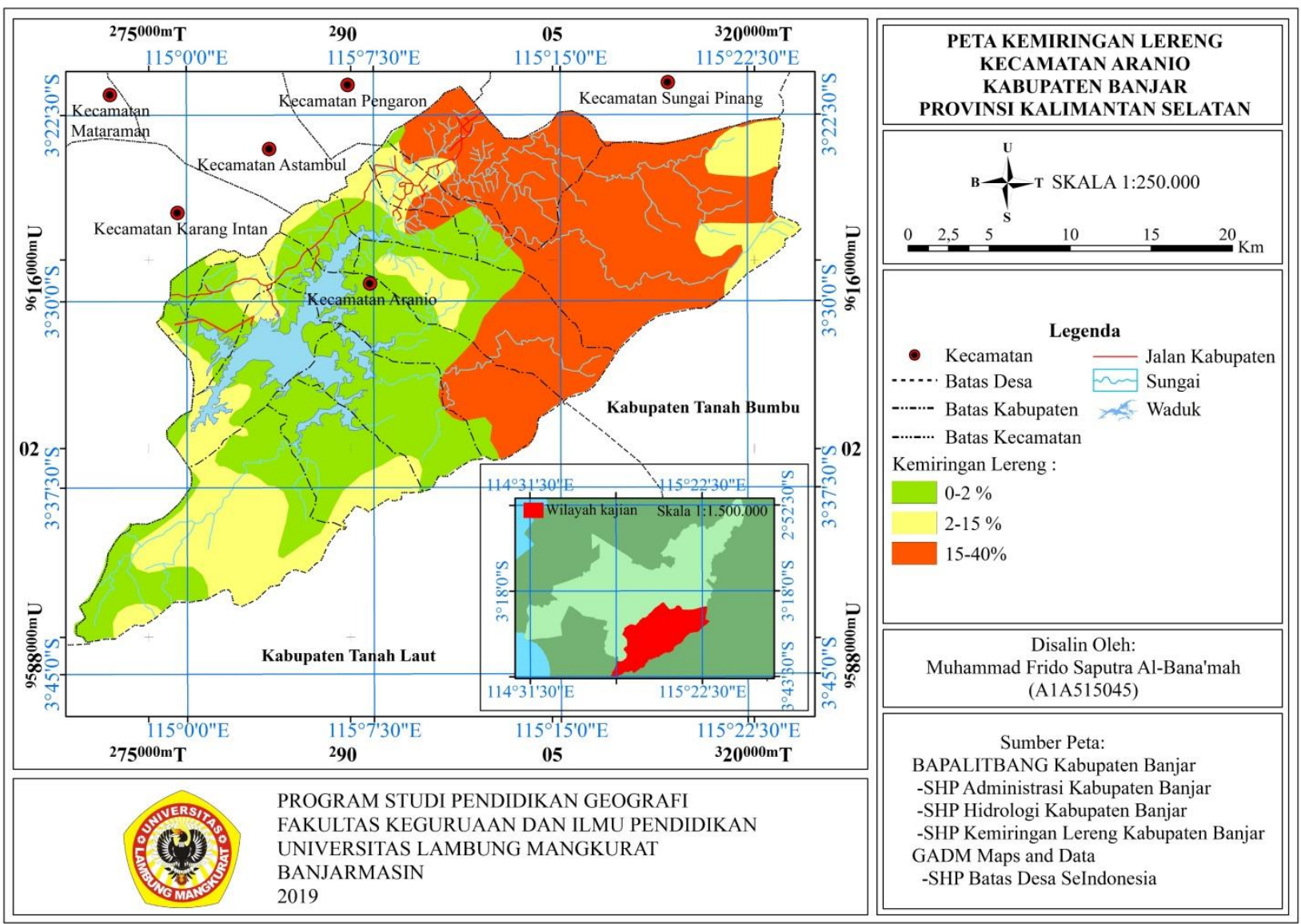

Lampiran 5. Peta kemiringan lereng di Kecamatan Aranio 